\title{
FAKTOR-FAKTOR YANG MEMENGARUHI KEPUTUSAN PEMILIHAN TEMPAT PERSALINAN PASIEN POLIKLINIK KESEHATAN IBU DAN ANAK DI KLINIK KELUARGA PISANGAN BARU, JAKARTA
}

\author{
Cindy Claudia Pandoyo Putri, Martinus Tjhia Tjen Jong, Innocentius Bernarto
}

Universitas Pelita Harapan Tangerang

\section{A R T I C L E I N F O}

\section{Keywords:}

Keywords: patient behavior, family roles, service fees, medical personnel services, distance, promotion, facilities of services, decision on choosing the place of delivery

Kata Kunci: perilaku pasien, peran keluarga, biaya pelayanan, pelayanan tenaga medis, jarak, promosi, fasilitas pelayanan, keputusan pemilihan tempat bersalin

\section{Abstract}

The purpose of this study was to evaluate the factors that influence the decision on the place of delivery at the Maternal and Child Polyclinic (KIA), Clinic of the Keluarga Pisangan Baru (KPB). The data research technique uses quantitative methods which are carried out by giving questionnaires in the form of scale questions and direct interviews with respondents. In this study, the target population was all pregnant women at the KIA Polyclinic from October to November 2020. Purposive sampling is apllied in this research. The number of samples is 136 respondents. Then, the data were processed using the Partial Least Squares-Structural Equation Modeling (PLS-SEM) technique with the help of SmartPLS software. The results showed that patient behavior, distance, medical personnel services, service facilities, promotions and family roles do not have a positive effect on the decision to choose the place of delivery. Service costs do not have a negative effect on the decision to choose the place of delivery. The role of family, service facilities, and service costs have a positive effect on patient behavior. Meanwhile, distance, medical personnel service, and promotion did not have a positive effect on patient behavior.

\section{Corresponding author:}

Cindy Claudia Pandoyo Putri pandoyo.c@gmail.com

\begin{abstract}
Abstrak
Tujuan penelitian ini adalah untuk mengevaluasi faktor-faktor yang memengaruhi keputusan tempat persalinan di Poliklinik Ibu dan Anak (KIA), Klinik Keluarga Pisangan Baru (KPB). Teknik penelitian data mengunakan metode kuantitatif yang dilakukan dengan pemberian kuesioner berupa pertanyaan berskala dan wawancara langsung dengan responden. Dalam penelitian ini target populasi adalah seluruh ibu hamil di Poliklinik KIA dalam kurun waktu Oktober-November 2020. Purposive sampling diterapkan dalam penelitian ini. Jumlah sampel sebanyak 136 responden. Kemudian, data diolah menggunakan tehnik Partial Least Squares Structural Equation Modeling dengan bantuan program SmartPLS. Hasil penelitian menunjukkan bahwa perilaku pasien, jarak, pelayanan tenaga medis, fasilitas pelayanan, promosi dan peran keluarga tidak berpengaruh positif terhadap keputusan pemilihan tempat persalinan. Biaya pelayanan tidak berpengaruh negatif terhadap keputusan pemilihan tempat persalinan. Peran keluarga, fasilitas pelayanan, dan biaya pelayanan berpengaruh positif terhadap perilaku pasien. Sedangkan, jarak, pelayanan tenaga medis, dan promosi tidak berpengaruh positif terhadap perilaku pasien.
\end{abstract}




\section{PENDAHULUAN}

Persalinan yakni suatu prosedur pengeluaran hasil konsepsi (embrio dan plasenta) secara fisiologis dari rahim ke dunia luar melewati jalan lahir ataupun jalan lain dengan bantuan ketika usia kehamilan sudah memadai (37-42 minggu) (World Health Organization, 2013). Masalah yang diidentifikasi pada kehamilan dan persalinan, termasuk angka kematian ibu (AKI), dipengaruhi oleh status kesehatan ibu, penilaian selama kehamilan, bantuan selama persalinan dan perawatan pasca persalinan (Susiana, 2019). Dalam upaya mengurangi AKI dan angka kematian bayi (AKB), baiknya ibu hamil melengkapi kunjungan rutin kepada penyedia pelayanan yang kompeten untuk meminimalkan elemen yang dapat berdampak pada kesehatan ibu dan bayi tersebut melalui pelayanan antenatal.

Melalui data yang dikumpulkan oleh Klinik Keluarga Pisangan Baru, angka persalinan yang ditangani di pelayanan pertolongan persalinan pada setiap bulannya berkisar 20-30 ibu hamil di tahun 2019-2020, sedangkan angka kunjungan ibu hamil untuk layanan antenatal mencapai 300-400 kunjungan setiap bulannya dengan 100-150 kunjungan di antaranya merupakan pasien yang berbeda. Hal ini memungkinkan ibu hamil mempunyai rencana untuk tidak melakukan persalinan di Klinik Keluarga Pisangan Baru. Dengan data tersebut, penelitian dilakukan untuk mengetahui rencana persalinan pada ibu hamil di wilayah Pisangan Baru (Buana, 2019). Sehingga, penelitian ini dilakukan untuk melihat elemen-elemen yang mempengaruhi keputusan pemilihan tempat persalinan meliputi pengaruh peran keluarga, fasilitas pelayanan, perilaku pasien, biaya pelayanan, pelayanan tenaga medis, promosi, dan jarak terhadap keputusan pemilihan tempat persalinan.

\section{KAJIAN LITERATUR DAN PENGEMBANGAN HIPOTESIS}

\section{Hubungan perilaku pasien dengan keputusan pemilihan tempat persalinan}

Perilaku pasien dalam kebutuhan bantuan kesehatan yaitu dimana saat pasien merasakan keluhan atas penyakit ataupun kondisi yang pasien rasakan, lalu pasien mencari bantuan tenaga kesehatan di pelayanan fasilitas kesehatan guna penyelesaian dari masalah kesehatan yang dihadapi, berupa tindak lanjut terapi ataupun perawatan yang sesuai (Latunju dan Akinyemi, 2018). Menurut Green (dikutip dalam Notoatmodjo, 2005, p.134), perilaku pasien berupa kesehatan individu ataupun kelompok berdampak atas dasar beberapa elemen seperti pengetahuan, tingkah laku, keyakinan, nilai-nilai dan persepsi yang akan mempengaruhi motivasi perorangan maupun kelompok untuk bertindak. Berdasarkan penelitian Adam (2008), terbukti jika perilaku pasien terhadap keputusan pemanfaatan fasilitas kesehatan menurun setelah dipengaruhi oleh budaya maupun kepercayaan turun-menurun yang lebih memilih ke dukun, sehingga menunjukkan hubungan sejalan. Sehingga dapat dibentuk hipotesis yaitu:

- $\quad H_{1 a}:$ Perilaku pasien berpengaruh positif terhadap keputusan pemilihan tempat persalinan

Hubungan jarak, pelayanan tenaga medis, biaya pelayanan, fasilitas pelayanan, promosi, dan peran keluarga dengan perilaku pasien

Adam (2008) menyimpulkan hasil penelitian dimana jarak dan biaya pelayanan berhubungan negatif terhadap pemanfaatan layanan kesehatan, sedangkan perilaku petugas kesehatan dan fasilitas kesehatan berpengaruh positif terhadap penggunaan layanan. Penelitian Hasnah (2008) pun mengungkapkan hasil dimana perilaku pasien terhadap keputusan dalam pengobatan paska persalinan di wilayah kerja Puskesmas Maritengngae dipengaruhi oleh faktor sosial, budaya dan kepercayaan. Hasil penelitian Wijayanti (2006) 
mengungkapkan terdapat predisposing factor berupa pengetahuan dari promosi layanan, reinforcing factor berupa peran keluarga dan pelayanan tenaga medis, serta enabling factor berupa jarak yakni kemudahan akses, biaya pelayanan dan fasilitas penunjang yang baik terhadap perilaku responden dalam penggunaan jasa pengobatan alternatif Radiesthesi Medik. Dengan demikian dapat disusun hipotesis sebagai berikut:

- $H_{1 b:}$ Jarak berpengaruh positif terhadap perilaku pasien.

- $H_{1 c}$ : Pelayanan Tenaga Medis berpengaruh positif terhadap perilaku pasien.

- $H_{1 d}$ : Biaya Pelayanan berpengaruh positif terhadap perilaku pasien.

- $H_{l e}:$ Fasilitas Pelayanan berpengaruh positif terhadap perilaku pasien.

- Hif: Promosi berpengaruh positif terhadap perilaku pasien.

- $H_{l g}$ : Peran Keluarga berpengaruh positif terhadap perilaku pasien.

\section{Hubungan jarak dengan keputusan pemilihan tempat persalinan}

Jarak merupakan jumlah lintasan agar seseorang dapat mencapai fasilitas layanan kesehatan seperti puskesmas, klinik, rumah bersalin ataupun rumah sakit yang kemudahannya dinilai berdasarkan waktu tempuh yang diperlukan, jumlah jarak tempuh yang perlu dijalani serta dana yang dikeluarkan untuk mencapai tempat tersebut (Khudori, 2012). Menurut Jennifer (2019), usaha apapun (waktu, tenaga dan sebagainya) yang terlibat dalam setiap aktivitas akan meningkatkan rasa kepemilikan sehingga akan memengaruhi tindakan seseorang. Penelitian Nurlailah (2009) mengungkapkan hasil dimana terdapat perbandingan pemanfaatan pelayanan berjumlah yang cukup banyak pada pasien Jamkesmas dengan tempat tingggal dekat pelayanan kesehatan dikomparasi dengan pasien Jamkesmas yang tinggal jauh dari fasilitas pelayanan kesehatan. Dengan demikian hipotesis yang diajukan adalah:

- $H_{2}:$ Jarak berpengaruh positif terhadap keputusan pemilihan tempat persalinan

\section{Hubungan pelayanan tenaga medis dengan keputusan pemilihan tempat persalinan}

Pelayanan tenaga medis tercerminkan dari keramahan, kepedulian serta rasa empati yang tinggi yang diberikan tenaga medis ke pasien. Perilaku yang ditampilkan tenaga medis saat pelayanan menjadi salah satu elemen penting dalam menentukan pasien akan menggunakan jasa layanan di tempat tersebut kembali pada kemudian hari. Sehingga, pasien tidak ragu dalam pemilihan tempat untuk mereka berobat. Menggabungkan kemampuan individu, keluarga dan lingkungan sekitar, termasuk jumlah layanan kesehatan yang ditawarkan dan jumlah paramedis yang berpraktek akan mendorong keputusan pemilihan layanan kesehatan (Notoatmodjo, 2005). Hasil penelitian Nurlailah (2009) menyatakan bahwa pasien Jamkesmas lebih menggunakan kembali jasa pelayanan setelah bertemu dengan paramedis yang berperilaku baik dan bersikap ramah dibandingkan dengan tenaga medis yang dianggap memberikan pelayanan buruk dan menimbulkan rasa tidak ingin berobat kembali ke fasilitas pelayanan tersebut. Dengan demikian hipotesis yang diajukan adalah:

- $H_{3}$ : Pelayanan tenaga medis berpengaruh positif terhadap keputusan pemilihan tempat persalinan.

\section{Hubungan biaya pelayanan dengan keputusan pemilihan tempat persalinan}

Kotler et al., (2008) mengungkapkan bahwa harga adalah beban berupa biaya terhadap suatu barang maupun pelayanan, yang diganti dengan manfaat yang didapatkan sebab mempunyai atau menggunakan produk mapun jasa tersebut. Bagi Engel, Blackwell, Miniard (dikutip dalam Swastha \& Hani, 2000, p.3) bahwa 
biaya barang mempengaruhi pilihan pembelian. Biaya yang lebih tinggi akan membuat kewaspadaan yang lebih tinggi tentang bahaya moneter terkait dengan pembelian, yang dengan demikian mendorong pencarian yang lebih murah untuk item yang serupa. Berdasarkan penelitian Mitayani (2008) yang dilaksanakan di RSU Surya Husada Denpasar Bali diperoleh hasil penggunaan jasa pelayanan kesehatan didasari oleh biaya pelayanan yang perlu dibayarkan. Hasil penelitian Adam (2008), terungkap jika ketidakberdayaan masyarakat untuk membayarkan biaya pelayanan yang mahal menghasilkan rendahnya kainginan untuk mendapatkan layanan kesehatan. Dengan demikian hipotesis yang diajukan adalah:

\section{- $H_{4}$ : Biaya pelayanan berpengaruh negatif terhadap keputusan pemilihan tempat persalinan}

\section{Hubungan fasilitas pelayanan dan promosi dengan keputusan pemilihan tempat persalinan}

Fasilitas kesehatan ialah kelengkapan yang ditawarkan pada suatu tempat fasilitas pelayanan kesehatan (Abdurrahim, 2016). Kehadiran fasilitas kesehatan akan berdampak pada mentalitas dan perilaku pembeli terhadap permintaan jasa (Kotler \& Boom, 1987). Penilaian ini menyokong teori yang mengemukakan fasilitas yang lengkap, tata ruangan yang tepat akan memberikan pengaruh pada perilaku dan sikap pasien berupa rasa nyaman, aman dan kepuasan saat berkunjung. Tjiptono (2009), mengungkapkan jika fasilitas layanan berdampak pada pandangan pengguna jasa, dimana fasilitas lebih lengkap akan menjamin peminatan pasien di pelayanan kesehatan di negara tersebut.

Promosi ialah informasi tentang kesejahteraan yang akan meningkatkan mentalitas menuju perilaku sehat, dan dengan demikian membawa perubahan gaya hidup sehat (menyadari apa yang harus dilakukan dalam tujuan kesehatan, baik promotif, preventif, penyembuhan dan rehabilitasi) (Faizah, 2017). Hartono dan Bambang (2010) menjabarkan jika keputusan pelanggan guna pemilihan layanan fasilitas kesehatan terikat oleh beberapa unsur, seperti kelengkapan pengetahuan yang didapatkan serta aksesibiltas dalam pemenuhan informasi. Hal fundamental terkait promosi yakni mengajak pengguna agar memakai produk maupun jasa yang diiklankan. Penelitian Yenni, Marwati, dan Solikhah (2010) menunjukkan bahwa hasil adanya hubungan positif bermakna antara promosi, pelayanan tenaga medis, serta fasilitas kesehatan terhadap pemanfaatan pelayanan poliklinik kandungan di RSUD Banjarnegara. Hal serupa dijabarkan melalui hasil penelitian Nurianti (2012), dimana promosi berisikan pengetahuan medis dan pelayanan kesehatan yang diberikan berpengaruh positif signifikan terhadap pemanfaatan penolong persalinan pada Ibu Bersalin di wilayah kerja Puskesmas Binjai. Dengan demikian hipotesis yang diajukan adalah:

- $H_{5}$ : Fasilitas pelayanan berpengaruh positif terhadap keputusan pemilihan tempat persalinan

- $H_{6}$ : Promosi berpengaruh positif terhadap keputusan pemilihan tempat persalinan

\section{Hubungan peran keluarga dengan keputusan pemilihan tempat persalinan}

Terdapat dua macam keluarga, khususnya keluarga inti yang terdiri dari orangtua dan kerabat kandung. Terlebih lagi, keluarga prokreasi, khususnya pasangan hidup dan anak. Makna pentingnya keluarga ditunjukkan dari rerata pasien wanita hamil yang berkunjung saat antenatal care didampingi oleh ibu maupun suami pasien (Kotler et al., 2008). Tidak melulu sebagai influencer, keluarga pun dapat berperan sebagai pengambil keputusan yaitu keputusan terhadap suatu penawaran jasa dari fasilitas kesehatan. Engel, Blackwell, dan Miniard (1995) menyatakan bahwa keluarga sebagai decider yakni pembuat keputusan dalam keluarga memiliki andil dalam menentukan kemana uang yang dipunya akan digunakan untuk jasa ataupun barang tertentu serta merek manakah yang akan ditransaksikan. Pada penelitian Amrullah (2016) 
menunjukkan hasil peran keluarga berpengaruh positif dalam penggunaan layanan di Puskesmas Arjasa. Dengan demikian hipotesis yang diajukan adalah:

- $\quad H_{7}$ : Peran keluarga berpengaruh positif terhadap keputusan pemilihan tempat persalinan.



Gambar 1. Model Penelitian

Sumber: Fauzia (2014); Khudori (2012)

\section{METODE PENELITIAN}

Penelitian ini termasuk sebagai penelitian kausal karena faktor-faktor yang memengaruhi variabel terikat akan diteliti (Sekaran \& Bougie, 2013). Target populasi adalah seluruh ibu hamil di Poliklinik KIA dalam kurun waktu Oktober-November 2020. Teknik pengambilan sampel dengan purposive sampling dengan kriteria ibu hamil trimester III yang sedang melakukan antenatal care di Poliklinik Ibu dan Anak (KIA) Klinik Keluarga Pisangan Baru (KPB). Jumlah responden sebesar 136 ibu hamil. Pada penelitian ini teknik pengolahan data yang diaplikasikan adalah partial least square-structural equation modeling (PLS-SEM) dengan bantuan software SmartPLS 3.0. Item kuesioner untuk peran keluarga, pelayanan tenaga medis, biaya pelayanan, promosi, jarak dan keputusan bersalin diadaptasi dari Fauzia (2014) dan Putri (2016); item perilaku pasien didapatkan dari Feni (2010); item fasilitas pelayanan didasari pada Adam (2016). Estimasi pengukuran menggunakan 4 poin skala Likert yakni poin $1=$ sangat tidak setuju; $2=$ tidak setuju; $3=$ setuju; $4=$ sangat setuju.

\section{HASIL DAN ANALISIS PENELITIAN}

Karakteristik responden adalah salah satu aspek yang turut berpengaruh di dalam memahami suatu sampel dari populasi. Dalam penelitian ini karakteristik responden yang dimaksud adalah usia responden, tingkat pendidikan responden, pendidikan terakhir responden, pekerjaan responden, usia suami, pendidikan terakhir suami, pekerjaan suami, penghasilan perbulan (suami dan istri), dan jarak tempat tinggal ke klinik. 
Tabel 1. Data Demografi Responden

\begin{tabular}{|c|c|c|c|c|c|}
\hline Data Responden & \multicolumn{5}{|l|}{ Kategori } \\
\hline Usia Responden & $<20$ tahun & 20-35 tahun & \multicolumn{3}{|l|}{$>35$ tahun } \\
\hline Persentase (\%) & 3,0 & 88,2 & \multicolumn{3}{|l|}{8,8} \\
\hline $\begin{array}{l}\text { Pendidikan } \\
\text { Terakhir Ibu }\end{array}$ & SD & SMP & SMA & Diploma & Sarjana \\
\hline Persentase (\%) & 1,5 & 14,7 & 46,3 & 11,8 & 25,7 \\
\hline $\begin{array}{l}\text { Pekerjaan } \\
\text { Responden }\end{array}$ & $\begin{array}{l}\text { Ibu Rumah } \\
\text { Tangga }\end{array}$ & $\begin{array}{l}\text { Pegawai } \\
\text { Swasta }\end{array}$ & $\begin{array}{l}\text { Pegawai } \\
\text { Negeri Sipil }\end{array}$ & \multicolumn{2}{|c|}{ Wiraswasta } \\
\hline Persentase (\%) & 57,4 & 32,4 & 2,2 & \multicolumn{2}{|l|}{8,1} \\
\hline $\begin{array}{ll}\text { Usia } & \text { Suami } \\
\text { Responden }\end{array}$ & $<20$ tahun & 20-35 tahun & \multicolumn{3}{|l|}{$>35$ tahun } \\
\hline Persentase (\%) & 0 & 74,3 & \multicolumn{3}{|l|}{25,7} \\
\hline $\begin{array}{l}\text { Pendidikan } \\
\text { Terakhir Suami }\end{array}$ & $\mathrm{SD}$ & SMP & SMA & Diploma & Sarjana \\
\hline Persentase $(\%)$ & 4,4 & 11,8 & 45,6 & 9,6 & 28,7 \\
\hline $\begin{array}{l}\text { Pekerjaan Suami } \\
\text { Responden }\end{array}$ & $\begin{array}{l}\text { Tidak } \\
\text { Bekerja }\end{array}$ & $\begin{array}{l}\text { Pegawai } \\
\text { Swasta }\end{array}$ & $\begin{array}{l}\text { Pegawai } \\
\text { Negeri Sipil }\end{array}$ & \multicolumn{2}{|c|}{ Wiraswasta } \\
\hline Persentase (\%) & 2,2 & 67,6 & 4,4 & \multicolumn{2}{|l|}{25,7} \\
\hline $\begin{array}{l}\text { Penghasilan Total } \\
\text { Perbulan }\end{array}$ & $\begin{array}{l}<\quad \mathrm{Rp} \\
2.000 .000\end{array}$ & $\begin{array}{l}\text { Rp 2.000.000- } \\
5.000 .000\end{array}$ & \multicolumn{3}{|c|}{$>\operatorname{Rp} 5.000 .000$} \\
\hline Persentase (\%) & 4,4 & 39,7 & \multicolumn{3}{|l|}{55,9} \\
\hline Jarak & $<1 \mathrm{~km}$ & $1-5 \mathrm{~km}$ & \multicolumn{3}{|l|}{$>5 \mathrm{~km}$} \\
\hline Persentase $(\%)$ & 27,2 & 52,9 & \multicolumn{3}{|l|}{19,9} \\
\hline
\end{tabular}

Berdasarkan keterangan Tabel 1, maka dengan jumlah 16 responden atau setara $12 \%$ berada dalam resiko tinggi, maka dapat menjadi pertimbangan diperlukannya program penyuluhan atau pemberian perhatian khusus kepada resiko tinggi tersebut guna mengurangi angka kejadian komplikasi saat kehamilan, persalinan maupun setelah persalinan. Melalui kategori tingkat pendidikan responden dapat diketahui bahwa 62,5\% dari responden memiliki pendidikan terakhir yaitu SMA ke bawah, maka kemungkinan keinginan untuk mencari informasi mengenai kesehatan akan kurang dibandingan dengan responden pendidikan lebih tinggi. Sehingga sebagai penyedia pelayanan kesehatan, dapat menjadi pertimbangan untuk memberikan program penyuluhan. Pekerja dianggap berwawasan lebih luas jika dibandingkan dengan ibu rumah tangga, disebabkan oleh pergaulan luas yang melibatkan pergentian pengetahuan dan interaksi antar kerabat. Karena pergaulan yang lebih luas dimana pertukaran informasi serta interaksi dengan rekan atau teman sering dilakukan. Sehingga mayoritas responden yang merupakan ibu rumah tangga membutuhkan informasi lebih melalui penyuluhan ataupun promosi yang diberikan oleh pihak klinik guna meningkatkan kunjungan ANC serta pengetahuan pentingnya persalinan sehat di fasilitas kesehatan yang memadai.

\section{Outer Model}

Pengukuran model merupakan tahapan awal yang dilakukan dalam Metode PLS. Evaluasi pengukuran model akan dilakukan dengan pengujian validitas serta reliabilitas guna model indikator reflektif. Model indikator reflektif ialah model yang mengasumsikan bahwa kovarian item pengukurnya dipengaruhi oleh konstruk yang mendasarinya. Pengujian validitas dan reliabilitas untuk konstruk reflektif yaitu convergent validity, discriminant validity, dan internal consistency reliability (Ghozali \& Latan, 2015). Uji validitas dilakukan dengan menggunakan metode SmartPLS. Convergent validity atas model pengukuran melalui indikator yang merefleksikan dapat terlihat melalui hubungan antara item score/indikator dengan score konstruk yang dimiliki. Ukuran reflektif individual disebut tinggi apabila berhubungan di atas nilai 0,70 
dengan konstruk yang ingin diukur. Akan tetapi, pada riset tahap pengembangan skala, loading 0,50 hingga 0,60 masih dapat diterima (Ghozali \& Latan, 2015).

Tabel 2. Evaluasi Model Pengukuran

\begin{tabular}{|c|c|c|}
\hline \multicolumn{2}{|c|}{ Konstruk dan Item } & $\begin{array}{l}\text { Outer } \\
\text { Loading }\end{array}$ \\
\hline \multicolumn{3}{|c|}{ Peran Keluarga $(\mathrm{AVE}=0,80 ; \mathrm{CR}=0,92)$} \\
\hline PK1 & Keluarga memberikan informasi mengenai Klinik KPB & 0,89 \\
\hline PK2 & $\begin{array}{l}\text { Keluarga merekomendasi kan penggunaan layanan di Klinik } \\
\text { KPB }\end{array}$ & 0,93 \\
\hline PK3 & Keluarga sudah berlangganan sarana layanan di Klinik KPB & 0,85 \\
\hline \multicolumn{3}{|c|}{ Pelayanan Tenaga Medis $(\mathrm{AVE}=0,67 ; \mathrm{CR}=0,89)$} \\
\hline PTM1 & $\begin{array}{l}\text { Bidan / Dokter Kandungan cepat tanggap terhadap keluhan } \\
\text { Anda }\end{array}$ & 0,84 \\
\hline PTM2 & $\begin{array}{l}\text { Bidan / Dokter Kandungan memberikan perhatian khusus } \\
\text { kepada anda }\end{array}$ & 0,76 \\
\hline PTM3 & Bidan / Dokter Kandungan bersikap ramah & 0,88 \\
\hline PTM4 & Bidan / Dokter Kandungan berpenampilan rapih dan bersih & 0,78 \\
\hline \multicolumn{3}{|c|}{ Biaya Pelayanan $(\mathrm{AVE}=0,73 ; \mathrm{CR}=0,89)$} \\
\hline BP1 & $\begin{array}{l}\text { Tarif pelayanan yang ditetapkan sesuai dengan kualitas } \\
\text { pelayanan }\end{array}$ & 0,87 \\
\hline BP2 & Tarif pelayanan yang ditetapkan terjangkau & 0,89 \\
\hline BP3 & Tarif Klinik KPB lebih murah dari tempat bersalin lainnya & 0,79 \\
\hline \multicolumn{3}{|c|}{ Fasilitas Pelayanan $(\mathrm{AVE}=0,74 ; \mathrm{CR}=0,90)$} \\
\hline FP1 & Fasilitas pemeriksaan penunjang yang lengkap & 0,73 \\
\hline FP2 & Kebersihan Klinik KPB & 0,92 \\
\hline FP3 & Kenyamanan ruangan Klinik KPB & 0,92 \\
\hline \multicolumn{3}{|c|}{ Perilaku Pasien $(\mathrm{AVE}=0,56 ; \mathrm{CR}=0,87)$} \\
\hline PP1 & Keperluan pemberian imunisasi TT saat mengandung & 0,74 \\
\hline PP2 & Keperluan pemeriksaan kehamilan secara rutin & 0,76 \\
\hline PP3 & Keperluan pemberian tablet Fe pada saat hamil & 0,79 \\
\hline PP5 & $\begin{array}{l}\text { Persalinan di Klinik Bersalin merupakan langkah untuk } \\
\text { menyelamatkan persalinan }\end{array}$ & 0,79 \\
\hline PP7 & $\begin{array}{l}\text { Lebih memilih bersalin di tempat praktik dengan penolong } \\
\text { yang handal dan professional }\end{array}$ & 0,76 \\
\hline \multicolumn{3}{|c|}{ Promosi $(\mathrm{AVE}=0,77 ; \mathrm{CR}=\mathbf{0 , 9 1})$} \\
\hline $\mathrm{P} 1$ & Mengetahui informasi pelayanan dari media promosi & 0,74 \\
\hline $\mathrm{P} 2$ & Pesan promosi yang disampaikan menarik & 0,93 \\
\hline P3 & Pesan promosi mudah dipahami & 0,94 \\
\hline \multicolumn{3}{|c|}{$\operatorname{Jarak}(\mathrm{AVE}=\mathbf{0 , 7 4 ; C R = 0 , 8 6 )}$} \\
\hline JTT1 & Letak Klinik KPB strategis & 0,92 \\
\hline JTT2 & Klinik KPB terjangkau dengan sarana transportasi umum & 0,79 \\
\hline
\end{tabular}


Keputusan Bersalin (AVE=0,73; $\mathrm{CR}=0,84)$

KB1 Ibu memutuskan untuk bersalin di Klinik KPB $\quad 0,74$

KB2 Lebih memilih bersalin di fasilitas kesehatan (non-rumah) $\quad 0,96$ dengan penolong persalinan berupa tenaga kesehatan

Catatan: $\mathrm{AVE}=$ Average Variance of Extracted. $\mathrm{CR}=$ Composite Reliability

Pada Tabel 2 dapat dilihat nilai factor loading dari setiap indikator bernilai di atas 0,7 dan nilai AVE untuk seluruh variabel berada di atas 0,5. Nilai tersebut merupakan rule of thumb AVE untuk convergent validity. Dapat dilihat bahwa nilai factor loading dan AVE sudah memenuhi rule of thumb. Dengan demikian evaluasi pengukuran model akan dilanjutkan dengan pengujian discriminant validity untuk 24 item variabel.

Pengujian internal consistency reliability dilakukan dengan melihat nilai composite reliability. Rule of thumb yang digunakan adalah nilai composite reliability harus lebih besar dari 0,7 (Ghozali \& Latan, 2015). Pada Tabel 2 dapat dilihat hasil pengolahan data untuk pengujian internal consistency reliability. Dapat diketahui bahwa semua variabel atau konstruk telah memiliki internal consistency reliability yang baik. Oleh sebab itu, penelitian dapat dilanjutkan dengan mengevaluasi model struktural.

Tabel 3. Pengujian Discriminant Validity

\begin{tabular}{|c|c|c|c|c|c|c|c|c|}
\hline & $\begin{array}{l}\text { Biaya } \\
\text { Pelayanan }\end{array}$ & $\begin{array}{l}\text { Fasilitas } \\
\text { Pelayanan }\end{array}$ & Jarak & $\begin{array}{l}\text { Keputusan } \\
\text { Bersalin }\end{array}$ & $\begin{array}{l}\text { Pelayanan } \\
\text { Tenaga } \\
\text { Medis }\end{array}$ & $\begin{array}{l}\text { Peran } \\
\text { Keluarga }\end{array}$ & $\begin{array}{l}\text { Perilaku } \\
\text { Pasien }\end{array}$ & Promosi \\
\hline $\begin{array}{l}\text { Biaya } \\
\text { Pelayanan }\end{array}$ & 0,86 & & & & & & & \\
\hline $\begin{array}{l}\text { Fasilitas } \\
\text { Pelayanan }\end{array}$ & 0,66 & 0,87 & & & & & & \\
\hline Jarak & 0,31 & 0,45 & 0,87 & & & & & \\
\hline $\begin{array}{l}\text { Keputusan } \\
\text { Bersalin }\end{array}$ & 0,26 & 0,37 & 0,11 & 0,86 & & & & \\
\hline $\begin{array}{l}\text { Pelayanan } \\
\text { Tenaga } \\
\text { Medis }\end{array}$ & 0,57 & 0,65 & 0,37 & 0,29 & 0,82 & & & \\
\hline $\begin{array}{l}\text { Peran } \\
\text { Keluarga }\end{array}$ & 0,37 & 0,35 & 0,34 & 0,30 & 0,25 & 0,90 & & \\
\hline $\begin{array}{l}\text { Perilaku } \\
\text { Pasien }\end{array}$ & 0,59 & 0,69 & 0,38 & 0,36 & 0,58 & 0,39 & 0,75 & \\
\hline Promosi & 0,35 & 0,36 & 0,30 & 0,28 & 0,31 & 0,41 & 0,30 & 0,88 \\
\hline
\end{tabular}

Pengujian discriminant validity dilakukan dengan melihat nilai cross loading. Rule of thumb yang digunakan adalah nilai korelasi item dalam satu variabel yang sama harus lebih besar dari nilai korelasi item tersebut dengan variabel lainnya. Pada Tabel 3 dapat dilihat hasil pengolahan data untuk pengujian discriminant validity.

Tabel 4. Pengujian Hipotesis 


\begin{tabular}{|l|c|c|c|}
\hline \multicolumn{1}{|c|}{ Hipotesis } & $\begin{array}{c}\text { Standardized } \\
\text { Path } \\
\text { Coefficient }\end{array}$ & thitung & Hasil \\
\hline $\begin{array}{l}\mathrm{H}_{1 \mathrm{a}} \text { : Perilaku pasien berpengaruh } \\
\text { positif terhadap keputusan pemilihan } \\
\text { tempat persalinan }\end{array}$ & 0,17 & 0,14 & $\begin{array}{c}\text { Tidak } \\
\text { Didukung }\end{array}$ \\
\hline $\begin{array}{l}\mathrm{H}_{1 \mathrm{~b}} \text { : Jarak berpengaruh positif } \\
\text { terhadap perilaku pasien }\end{array}$ & 0,04 & 0,57 & $\begin{array}{c}\text { Tidak } \\
\text { Didukung }\end{array}$ \\
\hline $\begin{array}{l}\mathrm{H}_{1 \mathrm{c}} \text { : Pelayanan Tenaga Medis } \\
\text { berpengaruh positif terhadap perilaku } \\
\text { pasien }\end{array}$ & 0,19 & 0,76 & $\begin{array}{c}\text { Tidak } \\
\text { Didukung }\end{array}$ \\
\hline $\begin{array}{l}\mathrm{H}_{1 \mathrm{~d}}: \text { Biaya Pelayanan berpengaruh } \\
\text { positif terhadap perilaku pasien }\end{array}$ & 0,17 & 1,75 & Didukung \\
\hline $\begin{array}{l}\mathrm{H}_{1 \mathrm{e}}: \text { Fasilitas Pelayanan berpengaruh } \\
\text { positif terhadap perilaku pasien }\end{array}$ & 0,40 & 3,53 & Didukung \\
\hline $\begin{array}{l}\mathrm{H}_{1 \mathrm{f}}: \text { Promosi berpengaruh positif } \\
\text { terhadap perilaku pasien }\end{array}$ & $-0,04$ & $-1,98$ & $\begin{array}{c}\text { Tidak } \\
\text { Didukung }\end{array}$ \\
\hline $\begin{array}{l}\mathrm{H}_{1 \mathrm{~g}}: \text { Peran keluarga berpengaruh } \\
\text { positif terhadap perilaku pasien }\end{array}$ & 0,15 & 2,24 & Didukung \\
\hline $\begin{array}{l}\mathrm{H}_{2}: \text { Jarak berpengaruh positif terhadap } \\
\text { keputusan pemilihan tempat } \\
\text { persalinan }\end{array}$ & $-0,14$ & $-1,32$ & $\begin{array}{c}\text { Tidak } \\
\text { Didukung }\end{array}$ \\
\hline $\begin{array}{l}\mathrm{H}_{3}: \text { Pelayanan tenaga medis } \\
\text { berpengaruh positif terhadap } \\
\text { keputusan pemilihan tempat } \\
\text { persalinan. }\end{array}$ & 0,07 & 0,48 & $\begin{array}{c}\text { Tidak } \\
\text { Didukung }\end{array}$ \\
\hline $\begin{array}{l}\mathrm{H}_{4}: \text { Biaya pelayanan berpengaruh } \\
\text { negatif terhadap keputusan pemilihan } \\
\text { tempat persalinan }\end{array}$ & $-0,09$ & $-0,70$ & $\begin{array}{c}\text { Tidak } \\
\text { Didukung }\end{array}$ \\
\hline $\begin{array}{l}\mathrm{H}_{5}: \text { Fasilitas Pelayanan berpengaruh } \\
\text { positif terhadap keputusan pemilihan } \\
\text { tempat persalinan. }\end{array}$ & 0,23 & 1,42 & $\begin{array}{c}\text { Tidak } \\
\text { Didukung }\end{array}$ \\
\hline $\begin{array}{l}\mathrm{H}_{6}: \text { Promosi berpengaruh positif } \\
\text { terhadap keputusan pemilihan tempat } \\
\text { persalinan. }\end{array}$ & 0,13 & $\begin{array}{c}\text { Tidak } \\
\text { Didukung }\end{array}$ \\
\hline $\begin{array}{l}\mathrm{H}_{7}: \text { Peran keluarga berpengaruh } \\
\text { positif terhadap keputusan pemilihan } \\
\text { tempat persalinan. }\end{array}$ & 0,16 & Didukung \\
\hline
\end{tabular}

Pada Tabel 4 dapat dilihat tingkat signifikansi dari hubungan antar variabel. Tingkat signifikansi ditunjukkan dengan memperhatikan besarna nilai thitung lebih kecil daripada tabel $(=1,65)$. Sedangkan pengaruh antar variabel ditunjukkan melalui nilai pada kolom Standardized Path Coefficient.

Table 5. Hasil Uji R-square 


\begin{tabular}{|c|c|}
\hline Variabel & $R$-square \\
\hline Keputusan Pemilihan Tempat Persalinan & 0,21 \\
\hline Perilaku Pasien & 0,55 \\
\hline
\end{tabular}

Setelah melakukan evaluasi pengukuran model, tahapan yang selanjutnya akan dilakukan yaitu evaluasi struktural model. Evaluasi struktural model dilakukan untuk menjelaskan pengaruh substantif variabel laten eksogen tertentu terhadap variabel laten endogen. Pada Tabel 5 dapat dilihat bahwa nilai $R$-square pada variabel keputusan pemilihan tempat persalinan adalah 0,21 . Hal ini berarti variabel keputusan pemilihan tempat persalinan dapat dijelaskan oleh variabel perilaku pasien, pengaruh keluarga, jarak, biaya pelayanan, fasilitas pelayanan, promosi, pelayanan tenaga medis sebesar $21 \%$. Sedangkan variabel perilaku pasien dapat dijelaskan oleh variabel pengaruh keluarga, promosi, jarak, fasilitas pelayanan, pelayanan tenaga medis dan biaya pelayanan sebanyak 55\%. Rule of thumb dari $R$-square adalah 0,75 , 0,5, dan 0,25 yang secara berturut-turut berarti kemampuan model dalam menjelaskan variabel kuat, sedang, dan lemah. Dalam penelitian ini kemampuan variabel keputusan pemilihan tempat persalinan adalah lemah, kemampuan variabel perilaku pasien adalah sedang adalah sedang (Ghozali \& Latan, 2015).

\section{PEMBAHASAN}

Hasil uji hipotesis pertama $\left(\mathrm{H}_{1 \mathrm{a}}\right)$ yakni perilaku pasien memberikan pengaruh positif terhadap keputusan pemilihan tempat persalinan adalah tidak didukung. Dimana semakin baik perilaku pasien terhadap kesehatannya, maka tidak berpengaruh pada perencenaan untuk menentukan tempat persalinan di Klinik Keluarga Pisangan Baru. Hasil ini tidak sejalan dengan hasil penelitian dari Adam (2008) dan Hasnah (2008) menyatakan dimana perilaku pasien terhadap keputusan pemanfaatan fasilitas kesehatan menurun setelah dipengaruhi oleh budaya maupun kepercayaan turun-menurun yang lebih memilih ke dukun, sehingga menunjukkan hubungan sejalan.

Hasil pengujian hipotesis $\mathrm{H}_{1 \mathrm{~d}}, \mathrm{H}_{1 \mathrm{e}}$ dan $\mathrm{H}_{1 \mathrm{~g}}$ yakni pengaruh biaya pelayanan, fasilitas pelayanan, dan peran keluarga berpengaruh positif terhadap perilaku pasien adalah didukung. Semakin baik biaya pelayanan, fasilitas pelayanan, dan peran keluarga, maka semakin baik perilaku pasien dalam menentukan tempat persalinan. Hal ini sejalan dengan hasil penelitian terdahulu dari Wijayanti (2006) yang menyatakan predisposing factor berupa pengetahuan dari promosi layanan, reinforcing factor berupa peran keluarga dan pelayanan tenaga medis, serta enabling factor berupa jarak yakni kemudahan akses, biaya pelayanan dan fasilitas penunjang yang baik terhadap perilaku responden dalam penggunaan jasa pengobatan alternatif Radiesthesi Medik., Sedangkan hasil pengujian hipotesis $\mathrm{H}_{1 \mathrm{~b}}, \mathrm{H}_{1 \mathrm{c}}, \mathrm{H}_{1 \mathrm{f}}$ yakni pengaruh jarak, pelayanan tenaga medis, dan promosi berpengaruh positif terhadap perilaku pasien adalah tidak didukung. Hal ini maka tidak sejalan dengan hasil penelitian terdahulu dari Wijayanti (2006). Selain itu, Adam (2008) menyimpulkan hasil penelitian dimana jarak dan biaya pelayanan berhubungan negatif terhadap pemanfaatan layanan kesehatan, sedangkan perilaku petugas kesehatan dan fasilitas kesehatan berpengaruh positif terhadap penggunaan layanan.

Hasil penelitian $\mathrm{H}_{2}$ dan $\mathrm{H}_{3}$ yakni jarak dan pelayanan tenaga medis memberikan pengaruh positif pada keputusan pemilihan persalinan adalah tidak didukung. Hasil penelitian ini menunjukkan bahwa meski jarak jauh atau letak klinik tidak strategis dan sulit dijangkau oleh kendaraan umum, tidak berpengaruh dalam penentuan tempat bersalin di Klinik KPB. Hal ini tidak sejalan dengan penelitian terdahulu dari Nurlailah (2009) yang menunjukkan asil dimana terdapat perbandingan pemanfaatan pelayanan berjumlah yang cukup banyak pada pasien Jamkesmas dengan tempat tingggal dekat pelayanan kesehatan dikomparasi dengan pasien Jamkesmas yang tinggal jauh dari fasilitas pelayanan kesehatan. Serta dalam penelitian 
Nurlailah (2009) disampaikan jika pasien Jamkesmas lebih menggunakan kembali jasa pelayanan setelah bertemu dengan paramedis yang berperilaku baik dan bersikap ramah dibandingkan dengan tenaga medis yang dianggap memberikan pelayanan buruk dan menimbulkan rasa tidak ingin berobat kembali ke fasilitas pelayanan tersebut.

Hasil penelitian $\mathrm{H}_{4}$ yakni biaya pelayanan memberikan pengaruh negatif pada keputusan pemilihan tempat persalinan adalah tidak didukung. Semakin murah biaya pelayanan tidak berpengaruh pada keputusan pasien untuk bersalin di Klinik Keluarga Pisangan Baru. Hal ini tidak sejalan dengan hasil penelitian Mitayani (2008) yang menyatakan biaya pelayanan yang rendah yang perlu dibayarkan mendasari paisen dalam penggunaan jasa pelayanan kesehatan di RSU Surya Husada Denpasar.

Hasil penelitian $\mathrm{H}_{5}$ dan $\mathrm{H}_{6}$ yakni fasilitas pelayanan dan promosi memberikan pengaruh positif pada keputusan pemilihan tempat persalinan adalah tidak didukung. Semakin baik promosi dan fasilitas pelayanan yang diberikan tidak berpengaruh pada pemilihan tempat persalinan. Hal ini tidak sejalan dengan hasil penelitian terdahulu dari Yenni et al., (2010) yang mengungkapkan hasil adanya hubungan positif bermakna antara promosi, pelayanan tenaga medis, serta fasilitas kesehatan terhadap pemanfaatan pelayanan poliklinik kandungan di RSUD Banjarnegara. Penelitian lain yang tidak sejalan yaitu Nurianti (2012) dimana promosi berisikan pengetahuan medis dan pelayanan kesehatan yang diberikan berpengaruh positif signifikan terhadap penggunaan penolong persalinan pada Ibu Bersalin di wilayah kerja Puskesmas Binjai.

Hasil penelitian $\mathrm{H}_{7}$ yakni peran keluarga memberikan pengaruh positif pada keputusan pemilihan tempat persalinan. tempat persalinan adalah tidak didukung. Semakin baik pengaruh peran keluarga tidak memberikan pengaruh pada pemilihan tempat persalinan. Hal ini tidak sejalan dengan hasil penelitian Amrullah (2016) yang menunjukkan hasil peran keluarga berpengaruh positif dalam penggunaan layanan di Puskesmas Arjasa.

\section{KESIMPULAN}

Berdasarkan analisis data dapat disimpulkan bahwa jarak, pelayanan tenaga medis, dan promosi tidak berpengaruh positif terhadap perilaku pasien. Kemudian biaya pelayanan, fasilitas, dan peran keluarga berpengaruh positif terhadap perilaku pasien. Berikutnya, perilaku pasien, jarak, pelayanan tenaga medis, fasilitas pelayanan, promosi, dan peran keluarga tidak berpengaruh positif terhadap keputusan pemilihan tempat persalinan. Terakhir, biaya pelayanan tidak berpengaruh negatif terhadap keputusan pemilihan tempat persalinan.

Penelitian dalam jenis kuantitatif ini melibatkan keterampilan pengamatan dan daya ingat peneliti selama melakukan observasi serta kelemahan peneliti dalam pencatatan selama membantu responden mencatat jawaban kuesioner. Selain itu terdapat keterbatasan waktu dan tempat penelitian, terjadi karena penyusunan penelitian dilakukan saat wabah Covid-19 sehingga pergerakan untuk wawancara terbatas oleh waktu, dan pemilihan tempat dilakukan pada kerabat yang kenal saja dikarenakan sulit mendapatkan kepercayaan dari pihak yang tidak dikenal disebabkan oleh pembatasan sosial. Saran untuk penelitian selanjutnya dapat dilakukan penelitian dengan menginklusi data demografis yang serupa, tidak terlalu jauh variabilitasnya. Serta, penelitian dapat diperluas dengan follow up lanjutan apakah ibu-ibu yang mengatakan akan memilih persalinan di Klinik KPB benar melahirkan di klinik tersebut. Hal ini dikarenakan belum terlihat jelas mengapa angka persalinan tidak mencapai target yang diharapkan, maka dapat diselidiki faktor apa yang mendorong keputusan akhir pemilihan tempat bersalin. 


\section{DAFTAR PUSTAKA}

Abdurrahim, A. (2016). Faktor-Faktor yang berhubungan dengan pemilihan tempat bersalin pada ibu hamil (Studi kasus di Kelurahan Rowosari, Kecamatan Tembalang, Kota Semarang). Semarang: Universitas Diponogoro.

Adam, B. (2008). Analisis pemanfaatan pelayanan kesehatan masyarakat Suku Bajo di Kabupaten Kolakasulawesi Tenggara Tahun 2008. Makassar: Universitas Hassanudin.

Adam, M. B. (2016). Survei gambaran kebersihan, kenyamanan, dan keamanan di puskesmas dan klinik mitra BPJS menurut perspektif pasien jaminan kesehatan nasional. Jakarta: Universitas Islam Negeri Syarif Hidayatullah.

Alas, R., Übius, U., Lorents, P., \& Matsak, E. (2017). Corporate Social Responsibility In European And Asian Countries. Jurnal Manajemen Bisnis Dan Inovasi (JMBI) UNSRAT Vol. 4 No. 1

Amrullah, A. (2016). Hubungan peran keluarga dengan pelayanan Puskesmas pada anggota keluarga yang menderitas penyakit kusta. Jurnal Keperawatan Muhammadiyah, 1(1), 72-78.

Buana, Y. (2019, February 15). Capaian kunjungan pasien di Klinik Keluarga Pisangan Baru. Retrieved January 31, 2021, from https://kusumabuanafoundation.blogspot.com/2019/02/capaian-kunjunganpasien-di-klinik.html

Faizah, N., \& Lestari U. (2017). Peran promosi kesehatan terhadap tingkat motivasi pasien mendapatkan layanan fisioterapi di Puskesmas Bantimurung. BKM Journal of Community Medicine and Public Health, 33 (6), 293-298.

Fauzia R. (2014). Faktor-faktor yang berhubungan dengan keputusan pemilihan tempat persalinan pasien poliklinik kandungan dan kebidanan di rumah sakit ibu dan anak Kemang Medical Care tahun 2014. Jakarta: Universitas Islam Negeri Syarif Hidayatullah.

Feni I. (2010). Kuesioner: Pengetahuan, sikap dan perilaku ibu bersalin oleh paraji tentang persalinan aman di wilayah kerja Puskesmas Tipar Kecamatan Citamiang Kota Sukabumi. Jawa Barat: Universitas Kristen Maranatha.

Ghozali, I. \& Latan, H. (2015). Partial least squares: Konsep, teknik, dan aplikasi menggunakan program SmartPLS 3.0 untuk penelitian empiris. Bulaksumur: BPFE Universitas Gadjah Mada.

Hartono \& Bambang. (2010). Manajemen pemasaran untuk rumah sakit. Jakarta: PT. Rineka Cipta.

Hasnah, A. (2008). Pengambilan Keputusan Ibu Pasca Persalinan dalam Memilih Pelayanan Kesehatan di Kabupaten Sidrap. Media Farmasi, 3(14), 34-40.

Jennifer W., (2019). Is having a sense of belonging important? Retrieved September 18, 2020, from https://www.mayoclinichealthsystem.org/hometown-health/speaking-of-health/is-having-a-sense-ofbelonging-important

Khudori. (2012). Analisis faktor-faktor yang mempengaruhi keputusan pemilihan tempat persalinan pasien Poliklinik Kandungan dan Kebidanan Rumah Sakit IMC Bintaro tahun 2012. Tesis. Depok: Fakutlas Kesehatan Masyarakat Universitas Indonesia.

Kotler, P., \& Boom, P.N. (1987). Tehnik dan strategi memasarkan jasa profesional. Jakarta: Intermedia. 
Kotler, P. \& Keller, K.L. (2008). Manajemen pemasaran.13th ed. Indonesia: PT. Macanan Jaya Cemerlang. Latunju, O. O., \& Akinyemi, O. O. (2018). Factors influencing health-seeking behaviour among civil servants in Ibadan, Nigeria. Annals of Ibadan postgraduate medicine, 16(1), 52-60.

Mitayani, N. N. (2009). Pengaruh Kepuasan Pasien Terhadap Pemanfaatan Kembali Jasa Pelayanan Kesehatan di Instalasi Rawat Inap Bangsal Penyakit Dalam Rumah Sakit Umum Surya Husadha Denpasar-Bali Tahun 2008. Retrieved September 23, 2020, from http ;//skripsistikes.wordpress.com/2009/05/04/ikmii33.

Mojambo, G. A., Tulung, J. E., \& Saerang, R. T. (2020). The Influence of Top Management Team (TMT) Characteristics Toward Indonesian Banks Financial Performance During The Digital Era (20142018). JMBI UNSRAT (Jurnal Ilmiah Manajemen Bisnis dan Inovasi Universitas Sam Ratulangi)., 7(1).

Nurianti, I. (2012). Pengaruh Faktor Predisposisi, Pendukung dan Kebutuhan Terhadap Pemanfaatan Penolong Persalinan Pada Ibu Bersalin di Wilayan Kerja Puskesmas Binjai Serbangan Kabupaten Asahan. Medan: Universitas Sumatera Utara.

Nurlailah. (2009). Analisis Faktor-faktor yang berhubungan dengan pemanfaatan pelayanan kesehatan di Puskesmas dan jaringannya oleh peserta Jamkesmas (Studi kasus : Kec. Baturaja Barat Kab. Oku). Universitas Indonesia.

Notoatmodjo, S. (2005). Metodologi penelitian kesehatan dan promosi kesehatan. Jakarta: PT. Rineka Cipta.

Putri, M.D. (2016). Faktor-faktor yang berhubungan dengan pemilihan tempat persalinan tahun 2015. Jurnal Kesehatan Masyarakat, 4(2), 55-67.

Sekaran, U., \& Bougie, R. (2013). Research method for business a skill building approach: $\sigma^{\text {th }}$ ed. New York: Willey.

Susiana, S. (2019). Angka kematian ibu: Faktor penyebab dan upaya penanganannya, Retrieved September 23, 2020, from http://berkas.dpr.go.id/puslit/files/info_singkat/Info\%20Singkat-XI-24-II-P3DIDesember-2019-177.pdf

Swastha, B., \& Hani, T. (2000). Manajemen pemasaran analisa perilaku konsumen (1 ${ }^{\text {st }}$ ed). Yogyakarta: BPFE-Yogyakarta.

Tjiptono, F. (2009). Service marketing: Esensi \& aplikasi. Yogyakarta: Marknesis.

Wijayanti, B. A. (2016). Predisposing, Enabling, dan Reinforcing Factors pada Pasien di Pengobatan Alternatif Radiesthesi Medik. Jawa Timur: Universitas Airlangga.

World Health Organization. (2013). Buku Saku Pelayanan Kesehatan Ibu di Fasilitas Kesehatan Dasar dan Rujukan. Jakarta: Bakti Husada Kementrian Kesehatan RI.

Yenni, A., Marwati, T., \& Solikhah. (2010). Faktor-faktor yang mempengaruhi pemanfaatan pelayanan Poli Obsgyn di RSUD Banjarnegara. Jurnal Fakultas Kesehatan Masyarakat, 4(3), 196-205. 